\title{
2018 FIFA World Cup: isolating Russia could harm global health
}

Wolfe, Sven Daniel

\begin{abstract}
Western sanctions have isolated Russia from key international systems. Putting aside controversial questions about Russia's motivations for retaking Crimea, their involvement in the Donbas region, or even the potential for sanctions to bring peace, the west faces unexpected health-related dangers in its pursuit of the politics of isolation.
\end{abstract}

DOI: https://doi.org/10.1016/S0140-6736(15)60316-6

Posted at the Zurich Open Repository and Archive, University of Zurich ZORA URL: https://doi.org/10.5167/uzh-111028

Journal Article

Accepted Version

Originally published at:

Wolfe, Sven Daniel (2015). 2018 FIFA World Cup: isolating Russia could harm global health. Lancet, 385(9970):749750 .

DOI: https://doi.org/10.1016/S0140-6736(15)60316-6 


\section{FIFA World Cup: isolating Russia could harm global health Sven Daniel Wolfe}

Published in The Lancet, vol. 385, No. 9970, p749-750, 28 February 2015

http://www.thelancet.com/journals/lancet/article/PIIS0140-6736(15)60316-6/fulltext

Western sanctions have isolated Russia from key international systems. Putting aside controversial questions about Russia's motivations for retaking Crimea, their involvement in the Donbas region, or even the potential for sanctions to bring peace, the west faces unexpected health-related dangers in its pursuit of the politics of isolation.

Away from the geopolitical stage, Russia has begun preparations for the 2018 FIFA World Cup. This mega-event will be hosted in 11 cities across European Russia, and could draw more than a million international spectators. The health risks involved in mass gatherings are well documented, and addressing them requires a collective multidisciplinary approach with regional, national, and international partners. ${ }^{1}$

The World Cup poses logistical and planning challenges, especially in terms of managing health risks. Implementing strategies to minimise these risks is a global priority that requires coordinated international effort and planning. The primary risks in mass gatherings are non-communicable diseases and injuries, although the potential global spread of communicable diseases also requires active monitoring. ${ }^{2}$ A proactive international approach that focuses on prevention and surveillance has provided a high level of public health protection during previous mass gatherings. ${ }^{3,4} \mathrm{New}$ technological solutions, such as web-based health surveillance networks and crowd-modelling software, are important for planning and executing a safe event. ${ }^{5,6}$

Unlike annual mass gatherings, the World Cup is a one-time ambulatory mega-event held at different locations. ${ }^{7} \mathrm{New}$ hosts can learn much from previous organising committees. To this end, Russia takes part in FIFA knowledge transfer events and has sent observers to mega-events in Poland, Ukraine, Brazil, and London. However, the health aspects of mega-event planning are often overlooked in favour of more visible concerns, such as infrastructure development, visitor accommodation, and security. When the Russia 2018 Local Organising Committee published its report on their preparatory activities, it made no mention of health planning. ${ }^{8}$

Under the aegis of World Cup preparations, the Russian Ministry of Health has secured funding for the repair and modernisation of 13 state-run health facilities in host cities. ${ }^{9}$ But a safe mega-event requires more than new infrastructure: the protection of health depends on rigorous surveillance and emergency planning. This advance work is contingent on extensive international collaboration, especially for the deployment of new technologies. Russia needs western partners to share best practices for risk assessment, 
communicable disease surveillance, and capacity building. However, the current context of sanctions and mistrust hampers this international cooperation.

Russia needs immediate international expert support to undertake effective public health measures in the 11 host cities, starting with risk assessments, disaster simulations, crowd behaviour models, and infectious disease surveillance mechanisms. Further, metapopulation modelling to simulate the spread of disease through human networks ${ }^{10}$ could also be useful for Russia in preparations for this event.

There are helpful precedents of international health-related collaboration during megaevent preparations in the nations of the former Soviet Union. During the run-up to the Sochi 2014 Winter Olympics, the local organising committee worked with WHO to implement a smoking ban during the event, part of a successful campaign to reduce tobacco use in 17 Russian cities. ${ }^{11}$ Further, WHO and Russia have published a strategy for cooperation that mentions mass gatherings medicine, but the focus is on general epidemic emergency response and does not mention specific plans for the upcoming World Cup. ${ }^{12}$ By contrast, to strengthen health-system preparedness in Poland and Ukraine during the run-up to the Union of European Football Associations European Football Championship Finals (Euro 2012), a daily health surveillance system was established through multicountry collaborations between local organising committees, WHO, and international public health organisations. ${ }^{13}$ Russia deserves the same. Instead of political isolation, Russia should be able to benefit from the experience of international experts.

For nearly a century, Russia has largely existed apart from western technological and economic flows, and even the fall of the Soviet Union did not eliminate the tendency of western policy makers and commentators to view Russia as an antagonist rather than as a partner. The upcoming 2018 World Cup offers a chance to repair this tumultuous relationship: international collaboration during mega-event preparations creates space in which new connections and institutions can grow.

The first step must be to end Russia's political and economic isolation. It is difficult to convince Russians of the west's friendly intentions while sanctions persist. ${ }^{14}$ Indeed, western sanctions have only served to boost President Vladimir Putin's approval ratings, and allowed him to marginalise Russia's moderates and opposition figures under the guise of defending the nation from international aggression. ${ }^{15}$ Unless current western attitudes change, it seems likely that Russia will prepare for the 2018 FIFA World Cup without the benefit of international collaboration - a situation that will increase health risks for all.

\section{References}


${ }^{1}$ Abubakar, I., Gautret, P., Brunette, G. et al. Global perspectives for prevention of infectious diseases associated with mass gatherings. Lancet Infectious Diseases 2012; 12: 66-74.

${ }^{2}$ Steffen, R., Bouchama, A., Johansson, A., et al. Non-communicable health risks during mass gatherings. Lancet Infectious Diseases 2012; 12, 142-149.

${ }^{3}$ Memish, Z.A., Alrabeeah, A.A., 2011. Jeddah declaration on mass gatherings health. Lancet Infectious Diseases 2011; 11: 342-343.

${ }^{4}$ Memish, Z.A., Stephens, G., Al Rabeeah, A. Mass gatherings medicine. Lancet Infectious Diseases 2012; 12, 10

${ }^{5}$ Memish, Z.A., Stephens, G.M., Steffen, R., Ahmed, Q.A. Emergence of medicine for mass gatherings: lessons from the Hajj. Lancet Infectious Diseases 2012; 12: 56-65

${ }^{6}$ Johansson, A., Batty, M., Hayashi, K., Al Bar, O., Marcozzi, D., Memish, Z.A., 2012. Crowd and environmental management during mass gatherings. Lancet Infectious Diseases 2012;

12: $150-156$

${ }^{7}$ Müller, M. What makes an event a mega-event? Definitions and sizes. Leisure Studies. 2015; 1-16. doi:10.1080/02614367.2014.993333 (published online Jan 13)

${ }^{8}$ Russia 2018 Local Organizing Committee Annual Report 2012.

$<$ http://www.fifa.com/mm/document/tournament/loc/02/07/81/59/2012-annual-report_eng.pdf> (accessed 25 January 2015)

${ }^{9}$ Russian Federal Government, decree No. 518. 20 June 2013. (in Russian). < http://www.minsport.gov.ru/documents/518.pdf> (accessed 10 January 2015)

${ }^{10}$ Khan, K., McNabb, S.J., Memish, Z.A. et al. Infectious disease surveillance and modelling across geographic frontiers and scientific specialties. Lancet Infectious Diseases 2012; 12, 222-230.

11 WHO. The Russian Federation aims for smoke-free Winter Games-new tobacco control measures are showing effects. http://www.who.int/features/2014/russia-antitobaccolaw/en/;February, 2014. (accessed Jan 21, 2015)

12 WHO Regional Office for Europe. Strategy of national cooperation. World Health Organization and Ministry of Health of the Russian Federation, ; 20142020http://www.who.int/countryfocus/cooperation_strategy/ccs_rus_russian.pdf. (accessed Jan 23, 2015)

${ }^{13}$ Smallwood, C.A.H., Arbuthnott, K.G., Banczak-Mysiak, B. et al. Euro 2012 European Football Championship Finals: planning for a health legacy. Lancet 2014; 383: 2090-2097.

${ }^{14}$ Levada. Russia's foreign policy: orientation and critiques, 2015. Levada Center poll on popular attitudes towards other nations and international criticism towards Russia. Levada Jan 13, 2015 (in Russian). <http://www.levada.ru/13-01-2015/vneshnyaya-politika-rossiiorientiry-i-kritika> (accessed 14 January 2015)

15 Levada. January approval ratings, 2015. Levada Center poll conducted regularly since 1999. Levada Jan 28, 2015 (in Russian). <http://www.levada.ru/28-01-2015/yanvarskiereitingi-odobreniya-i-doveriya> (accessed 28 January 2015) 